\title{
The Effect of the Blow flies (Diptera: Calliphoridae) on the Size and Weight of Mango (Mangifera indica L.)
}

Shafqat Saeed, Muhammad Nadir Naqqash, Waqar Jaleel, Qamar Saeed, Fozia Ghouri

Background: Pollination has a great effect on the yield of fruit trees. Blow flies are considered as an effective pollinator compared to hand pollination in fruit orchards.

Therefore, this study was designed to evaluate the effect of different pollination methods in mango orchards. Methodology: The impact of pollination on quantity and quality of mango yield by blow flies was estimated by using three treatments, i.e., open pollinated trees, trees were covered by a net in the presence of blow flies for pollination, and trees were covered with a net but without insects. Results: The maximum number of flowers was recorded in irregular type of inflorescence, i.e., 434.80flowers/inflorescence. Fruit setting (bud) was higher in open pollinated mango tree (i.e. 37.00/inflorescence) than enclosed pollination by blow flies (i.e. 22.34/inflorescence). The size of the mango fruit was the highest $(5.06 \mathrm{~mm})$ in open pollinated tree than the pollinated by blow flies $(3.93 \mathrm{~mm})$ and followed by without any pollinator $(3.18 \mathrm{~mm})$ at marble stage. We found maximum weight of mango fruit $(201.19 \mathrm{~g})$ in open pollinated trees. Discussion: The results demonstrated that blow flies can be used as effective mango pollinators along with other flies and bees. The blow flies have shown a positive impact on the quality and quantity of mango. This study will be helpful in future and also applicable at farm level to use blow

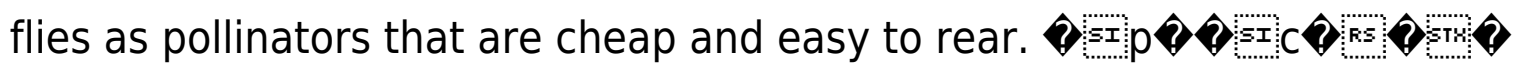




\section{Manuscript Title}

2 The Effect of the Blow flies (Diptera: Calliphoridae) on the Size and Weight of Mango

3 (Mangifera indica L.)

4 Running Title: Pollination in Mango by Blow flies

5 Authors:

6 Shafqat Saeed ${ }^{1 *}$, Muhammad Nadir Naqqash², Waqar Jaleel ${ }^{3}$, Qamar Saeed ${ }^{4}$, Fozia

7 Ghouri $^{3}$

$8{ }^{1}$ Department of Entomology, Muhammad Nawaz Sharif University of Agriculture, Multan, 9 Pakistan

$10{ }^{2}$ Department of Plant production and technologies, Faculty of Agricultural Sciences and 11 Technology, Niğde University, Turkey

$12{ }^{3}$ College of Agriculture, South China Agriculture University, Guangzhou, Guangdong 510642,

13 China

${ }^{4}$ Entomology, Faculty of Agricultural Sciences and Technology, Bahauddin Zakariya University,

15 Multan, Pakistan

16

17 *Corresponding Author

18 Email: bumblebeepak@gmail.com

19 Phone: 00923006358432

20 Fax: 009261921002 


\section{Abstract}

26 Background: Pollination has a great effect on the yield of fruit trees. Blow flies are considered

27 as an effective pollinator compared to hand pollination in fruit orchards. Therefore, this study

28 was designed to evaluate the effect of different pollination methods in mango orchards.

29 Methodology: The impact of pollination on quantity and quality of mango yield by blow flies

30 was estimated by using three treatments, i.e., open pollinated trees, trees were covered by a net in

31 the presence of blow flies for pollination, and trees were covered with a net but without insects.

32 Results: The maximum number of flowers was recorded in irregular type of inflorescence, i.e.,

33 434.80flowers/inflorescence. Fruit setting (bud) was higher in open pollinated mango tree (i.e.

34 37.00/inflorescence) than enclosed pollination by blow flies (i.e. 22.34/inflorescence). The size of

35 the mango fruit was the highest $(5.06 \mathrm{~mm})$ in open pollinated tree than the pollinated by blow flies

$36(3.93 \mathrm{~mm})$ and followed by without any pollinator $(3.18 \mathrm{~mm})$ at marble stage. We found maximum

37 weight of mango fruit $(201.19 \mathrm{~g})$ in open pollinated trees.

38 Discussion: The results demonstrated that blow flies can be used as effective mango pollinators

39 along with other flies and bees. The blow flies have shown a positive impact on the quality and

40 quantity of mango. This study will be helpful in future and also applicable at farm level to use

41 blow flies as pollinators that are cheap and easy to rear.

42 Key words: Blow flies, Mango, Pollination 
44

45

46

47

48

49

50

51

52

53

54

\section{Introduction}

Mango, Mangifera indica L., is very popular and economically important fruit. It is widely cultivated in the tropical and subtropical areas of the world (Stephen et al., 1984). Insect pollinators play a key role in maintaining global biodiversity by providing a key ecosystem that is crucial for maintenance of domesticated and wild plant communities. Decline in pollinators' fauna and parallel shrinkage of dependent plants is well documented in scientific literature (Potts et al., 2010). According to an estimate insect pollinators are responsible for $35 \%$ of global cropbased food production. About 87 crops, i.e. $70 \%$ of the 124 main crops used directly for human consumption in the world, their pollination depend upon the pollinators (Klein et al., 2007). Recently, the global economic value of pollination from domesticated and wild animals has been estimated at $€ 153$ billion (Gallai et al., 2009). Moreover, destruction of natural habitats resulting in decline of pollinators' fauna has laid the basis for discovery of potential of more insect pollinators to increase the yield (Hopwood et al. 2015).

Unfortunately, research regarding pollinators usually focus on hymenopterans, syrphids and butterflies. Therefore, all the ecology conservation schemes and other strategies are predominantly aimed to conserve these insects (Potts et al. 2006; Potts et al. 2009). Very little importance has been given to dipterans which consist of seventy-one families, including Mycetophilidae, Bibionidae, and Culicidae; Syrphidae, Bombyliidae, Conopidae, Stratiomyidae, and Nemestrinidae (lower Brachycera) and among the higher Brachycera (Cyclorrhapha); and many more (Kastinger \& Weber 2001; Larson et al. 2001; Rotheray \& Gilbert 2011). They contain regular visitors of more than 555 plant species (Larson et al. 2001). Non-syrphid Diptera are diverse, common and ubiquitous in both natural and managed habitats (Skevington \& Dang, 2002; Vanbergen et al. 2014). Among non-syrphid dipterans, members of family Calliphoridae 
67 (Schizophora, Calyptratae, Oestroidea) commonly known as blow flies, bluebottles, cluster flies

68

69

or greenbottles are very important pollinators. They are worldwide distributed, with over 1,000 species and about 150 genera described (Shewell, 1987; Vargas \& Wood, 2010). Blow flies thought to be the most dislike fly among all the flies of Dipteran, and it is a carrier of most of diseases and cause myiasis (Zumpt, 1965; Greenberg, 1973). This character has been recognized nearly 1500 years ago that flies are transmitters of diseases (Greenberg, 1973). Because earlier research was done only on negative aspects of flies but now most of the studies have shown that blow flies species have many beneficial aspects such as surgeons, pollinators, agents of decay, forensic indicators, and recreational uses (Jarlan et al., 1997; Losey \& Vaughan, 2006; Klein et al., 2007; Heath, 2015). Kugler $(1951,1956)$ conducted series of experiments and demonstrated that green bottle flies, blow flies and flesh flies (Sarcophaga sp.) favor yellow and white colored models over brown and purple ones in the presence of a sweet scent, but the opposite in the presence of a carrion scent while unscented models were ignored. Kumari et al 2014 survey was done in mango orchard during different times and reported that blow flies performed as pollinators in mango orchard gives better yield as compared to un pollinated trees.

Biology of mango pollinators have been studied in India and Israel, and their results demonstrated that insects of the Diptera and Hymenoptera play major roles in the pollination of this important fruit. Important examples of mango pollinators' are e.g. Apis dorsata F., Apis florea F., Episyrphis balteatus De Geer., Ischiodon scutellaris F. and lucilia spp (Singh, 1988; Bhatia et al., 1995; Singh, 1997; Dag \& Gazit, 2000). Use of these pollinators can significantly enhance the mango yield (Anderson et al. 1982; Dag \& Gazit, 2000). Considering the importance of beneficial aspects of blow flies in Pakistan, role of pollinators especially dipterans (blow flies) were never studied in Mangifera indica. The blow flies are the easier source of pollination as 
90 compared to other pollinators such as honey bees, syrphid flies, Xylocopa spp that are difficult to

91 rear (Faulkner, 1997). Moreover, all the stages of fruit development like formation of buds, pea

92 size, marble size fruit (weight and size) and stone stage are very important with respect to

93 development and economic yield of mango so impact of only blow flies and all pollinators was

94 investigated on these stages (Verghese, 1999). Considering the importance of beneficial aspects

95 of blow flies as role of pollinators especially which has been never studied in Mangifera indica.

96 Therefore, this research was conducted to evaluate the effects of blow flies on the mango

97 pollination and fruit yield and quality. The blow flies are the cheapest source of pollination as

98 compared to other pollinators, such as honey bees, syrphid flies, xylocopa spp that are expensive

99 to rear.

100 Material and methods

101 Plant material

102 The impact of pollination by blow fly on mango yield was studied in the orchard of

103 Faculty of Agricultural Science and Technology (FAS\&T), Bahauddin Zakariya University

104 Multan. A total of three trees and 10 branches from each tree were selected for recording the data.

105 Following treatments were used: 1) open pollinated trees; 2) Trees were covered by net and blow

106 flies were used for pollination; 3) Trees were covered by nets and no insect was kept inside the net

107 for pollination. Three replications were used for each treatment.

108 Rearing of blow fly for mango pollination

109 Adults of blow fly (Calliphora spp.) were collected from the different poultry farms of

110 Multan, Pakistan. Mass culture of blow flies was reared in Bio-Ecology Laboratory of Faculty of

111 Agricultural Science and Technology, Bahauddin Zakariya University, Multan Pakistan. Adults 
112 were released into the plastic cage $(18 \mathrm{~cm}$ in diameter and $24 \mathrm{~cm}$ in height) with diet (10 percent

113 honey solution), and chicken livers were also placed in the plastic trays for egg laying. The six

114 plastic cages were used for rearing blow flies. Then hatched larvae were separated into the plastic

115 pots $(4 \mathrm{~cm}$ in diameter and $8 \mathrm{~cm}$ in height) that were half filled with sterilized sand and $50 \mathrm{~g}$ chicken

116 liver. In each plastic pot, 20 larvae were released and maximum adults of blow flies were reared in

117 the laboratory for field application.

\section{Installation of cages}

Experiment was installed according to randomized complete block design (RCBD). Mango

trees with a height of $2.1 \mathrm{~m}$ and width of $2.4 \mathrm{~m}$ at the emergence of inflorescence were selected for

the installation of cages. The cages, made by muslin cloths, were used for the covering of mango

trees $(3.35 \times 3.35 \times 3.35$ meters $)$. A total of 100 adults of blow flies were released for pollination

efficacy in the covered mango trees (Fig 1) and control was free of all kinds of insect pollinators.

124 Ten branches were tagged in each tree for data recording.

\section{Data recording}

Total number of flowers and their types of inflorescences were counted in each treatment.

Data as number of flowers on each type of inflorescence, size $(\mathrm{mm})$ and weight $(\mathrm{g})$ of fruits at marble stage (30 days after the fruit set and have no stone (stage of seed) inside the fruit) of mango was recorded by tagging ten twigs in each repeating unit.

\section{Statistical analysis}


133 flowers, buds, fruits, size and weight of fruits were subjected to statistical analysis using analysis

134 of variance (ANOVA). Means were compared by use of least significance difference test at $\mathrm{p}=$

135 0.05. Data were analyzed using SAS program (SAS, 2011).

\section{Results}

137 Number of inflorescences was initially counted before pollination/treatment among each

138 type of inflorescence (conical, pyramid and irregular) (Table 1). Number of opened flowers

139 (327.97 \pm 25.92$)$ was significantly higher in open pollinated trees as compared to blow fly and

140 unpollinated cages $(\mathrm{F}=80.04 ; \mathrm{DF}=6 ; \mathrm{P}<0.01)$. While on irregular type of inflorescence, number

141 of opened flowers in the open pollinated mango trees was more i.e. $434.80 \pm 52.30$ /inflorescence

142 than unpollinated and blow fly pollinated trees $(\mathrm{F}=14.06 ; \mathrm{DF}=6 ; \mathrm{P}<0.01)$. Similar pattern was

143 recorded regarding numbers of opened flowers in pyramid type of inflorescence $(\mathrm{F}=54.06$;

$144 \mathrm{DF}=6 ; \mathrm{P}<0.01)($ Fig 2).

Highest number of buds/inflorescence were found in open mango pollinated trees

146 (2.67 $\pm 0.51 /$ inflorescence) than blow fly and without pollinators cage, in case of conical

147 inflorescence $(\mathrm{F}=13.3 ; \mathrm{DF}=6 ; \mathrm{P}<0.01)$. Data regarding pyramid type of inflorescence depicted

148 that maximum numbers of buds $(1.96 \pm 0.45 /$ inflorescence $)$ were observed in open pollinated trees

149 than blow fly and without pollinators cage trees $(\mathrm{F}=8.09 ; \mathrm{DF}=6 ; \mathrm{P}<0.01)$. Similar pattern of

150 results was found in case of irregular inflorescence where higher number of buds i.e.

$1511.93 \pm 0.47 /$ inflorescence were found as compared to rest of two treatments $(\mathrm{F}=15.02 ; \mathrm{DF}=6 ; \mathrm{P}$

$152<0.01$ ) (Fig 3). Significantly higher number of buds on conical inflorescence i.e.

$1533.53 \pm 0.05 /$ inflorescence was found in open trees than blow fly cage and unpollinated cages

$154(\mathrm{~F}=10.08 ; \mathrm{DF}=6 ; \mathrm{P}<0.001)$. Similarly, number of buds on pyramid inflorescence was

155 significantly higher i.e. 3.60 \pm 0.34 /inflorescence in open-pollinated trees than blow fly pollinated 
156 and unpollinated cages $(\mathrm{F}=17.07 ; \mathrm{DF}=6 ; \mathrm{P}<0.01)$. While, in case of irregular inflorescence

157 higher number of buds/inflorescences was found in blow fly pollinated trees

158 (4.16 \pm 0.11 inflorescence) than open and unpollinated trees $(\mathrm{F}=20.06 ; \mathrm{DF}=6 ; \mathrm{P}<0.01)$ (Fig 4). tested treatments in each type of inflorescence (conical, pyramid and irregular inflorescence). Number of fruits was significant maximum on conical inflorescence (1.20 \pm 0.20 /inflorescence) than blow fly and close cage/without pollinators trees $(\mathrm{F}=40.5 ; \mathrm{DF}=6 ; \mathrm{P}<0.05)$. Number of fruits $(1.24 \pm 0.21 /$ inflorescence) at marble stage on pyramid inflorescence was more in open

164 pollinated trees than other two treatments $(\mathrm{F}=5.38 ; \mathrm{DF}=6 ; \mathrm{P}<0.01)$. Higher number of 165 fruits/inflorescences was found in open pollinated mango tree, at marble stage, on irregular inflorescence $(1.36 \pm 0.20$ /inflorescence) than blow fly pollinated and unpollinated cages of trees $(\mathrm{F}=5.90 ; \mathrm{DF}=6 ; \mathrm{P}<0.01),($ Fig 5).

Average size and weight of mango fruits at marble stage varied significantly among the treatments. Average size of mango fruits i.e. $5.06 \pm 0.29 \mathrm{~mm}$ was statistically higher in open pollinated trees than blow fly pollinated cages and closed cages trees $(\mathrm{F}=7.47 ; \mathrm{df}=6 ; \mathrm{P}<0.01)$.

A similar pattern was also observed in case of weight of mango fruits where average weight of

172 mango i.e. $210.20 \pm 13.92 \mathrm{~g}$ was significantly higher as compared to blow fly pollinated cages and closed cages trees $(\mathrm{F}=16.07 ; \mathrm{df}=6 ; \mathrm{P}<0.01)$ (Fig 6). Data showed the positive correlation

174 between of size and weight of mango fruit at marble stage (Fig 7).

\section{Discussion}

176 A huge number of economically nutritive plants depend on different types of pollinators for 177 pollination (Eilers et al., 2011). Though modern farming techniques can produce higher yield of 178 crops (Aizen et al., 2008, 2009), but due to significant decline in insect pollinators primarily due 
179 to the isolation from natural habitats potential of modern farming techniques can't be fully

180 utilized (Klein et al., 2007; Garibaldi et al., 2011). In most of the habitats, pollinating flies

181 guarantee or enhance seed and fruit production of many plants such as medicinal, food and

182 ornamental plants. Due to the large gaps in the knowledge about the dipterans, there is a need to

183 address the role of diptera in pollination network. Dipteran flies have potential to survive in

184 variable ranges of temperature or environment our results support that blow fly have potential of 185 pollination (Ssymank et al., 2008; Munawar et al., 2011, Abrol, 2012).

186 A mango panicle contains around 200-4,000 flowers and a mature tree may has 187 approximately 600-1,000 panicles (Manning, 1995). About 46 kinds of pollinators belonging to 188 three orders i.e. coleoptera, diptera and hymenoptera are capable of pollinating mango flowers 189 (Singh, 1988; Bhatia et al., 1995; Singh, 1997; Dag \& Gazit, 2000). Mango inflorescence are 190 three types typical, conical and irregular and various insects visited for pollination (Heard, 1999).

191 These pollinators are very crucial for successful fruit set in mango (Free \& Williams, 1976; 192 Anderson et al., 1982; Richards, 2001; Carvalheiro et al., 2010). They are not only sensitive to 193 change in their natural habitat and/or niche, but are also sensitive to pesticides (De 194 Siqueira et al., 2008).

195 One of the main components of ecosystem are pollinators (Garibaldi et al., 2013). Pollinator 196 has two types as one is domesticated and other is wild pollinators, and both are very important 197 for the pollination of plants. Our result showed that open trees produced maximum yield, 198 followed by covered trees with blow flies and without insects. These results are consistent with 199 the previous study, who revealed that insects increase the yield of fruits by amplifying 200 pollination (Mingjian et al., 2003). Previous studies also demonstrated that diversity of 201 pollinators has greater impact on the yield of fruit trees and environmental hazards have declined 
202 the different types of pollinators (Jones \& Emsweller, 1934; Fajardo et al., 2009). In open

203 pollinated condition, mango size and weight were highly significant because of a variety of 204 pollinators e.g. Apis dorsata F., Apis florea F., Episyrphis balteatus De Geer., Ischiodon scutellaris 205 F. and lucilia spp at the farm (Bashir et al. 2013). Overall results showed that open pollinated 206 trees have maximum and good quality of fruits. However, blow flies also showed great impact 207 on mango pollination because higher quantity and better quality of fruits were recorded than 208 close cage trees.

209 Conclusion

The results revealed that fruit setting was better in open trees than blow flies and without

211 pollinated trees respectively. Mango weight and size of was significantly better in open trees

212 than blow flies and without pollinators. However, we detected fruits with maximum weight and

213 size in the open pollinated mango trees where more number of pollinators visit the trees for

214 pollination and resulted in the better quality and quantity of mango fruit. We concluded that blow

215 flies have the potential for pollination in $M$. indica. So this research will be helpful in future and

216 applicable at farm level where honey keeping in the orchard is difficult for pollination because of

217 environment and high cost. We speculated that blow flies are the best, cheaper source of

218 pollination as a replacement of honey bees and other pollinators which are expensive to purchase

219 and maintain in the orchards for pollination. Blow flies would be easily maintained in orchard by

220 providing diet like organic matter, dead birds etc in one side of mango orchard. This study also

221 showed that irregular type of inflorescence have maximum number of flowers, buds and fruits,

222 so the breeders could focus on to develop the variety of $M$. indica having more number of 223 irregular types of inflorescence. 
224

225

226

227

228

229

230

231

232

233

234

235

236

237

238

239

240

241

242

243

244

245

246

247

248

249

250

251

252

\section{References}

Abrol DP, 2012. Pollination in Cages. In Pollination Biology Springer Netherlands, 353-395.

Aizen MA, Garibaldi LA, Cunningham SA, Klein AM. 2008. Long-term global trends in crop yield and production reveal no current pollination shortage but increasing pollinator dependency. Current Biology 18: 1572-1575.

Aizen MA, Garibaldi LA, Cunningham SA, Klein AM. 2009. How much does agriculture depend on pollinators?. Lessons from long-term trends in crop production. Annals of Botany 103: 1579-1588.

Anderson DL, Sedgley H, Short JRT, Allwood AJ. 1982. Insect pollination of mango in northern Australia. Australian Journal of Agricultural Research 33: 541-548

Bashir MA, Saeed S, Sajjad A. 2013. Monitoring Hymenoptera and Diptera pollinators in a subtropical forest of Southern Punjab, Pakistan. Pakistan Journal of Agricultural Science 50: 359-366.

Bhatia R, Gupta D, Chandel JS, Sharma NK. 1995. Relative abundance of insect visitors on flowers of major subtropical fruits in Himachal Pradesh and their effect on fruit set. Indian Journal of Agriculture Science 65: 907-912.

Bluthgen N, Menzel, F, Blu"thgen N. 2006. Measuring specialization in species interaction networks. BMC Ecology 6: 9-13.

Carvalheiro LG, Seymour CL, Veldtman R, Nicolson SW. 2010. Pollination services decline with distance from natural habitat even in biodiversity-rich areas. Journal of Applied Ecology 47: 810-820.

Dag A, Gazit S. 2000. Mangopollinators in Israel. Jounal of Applied Horticulture 2: 39-43.

De Siqueira KMM, Kiill LHP, Martins $\quad$ CF, Lemos $\quad$ IB, Monteiro SP, Feirosa EA. 2008. Comparative study of pollination of Mangifera indica L. in conventional and organic crops in the region of the Submédio São Francisco valley. Revista Brasileira de Fruticultura 30: 303-310.

Eilers EJ, Kremen C, Greenleaf SS, Garber AK, Klein AM. 2011. Contribution of pollinatormediated crops to nutrients in the human food supply. PLoS ONE 6: e21363, doi: 10.1371/journal.pone.0021363. 
253 Fajardo JR, AC, Medina JR, Opina OS, Cervancia CR. 2009. Insect Pollinators and Floral 254 Visitors of Mango (Mangifera indica L. cv. Carabao). The Philippine Agricultural 255 Scientist 91: 34-38.

256 Faulkner GJ. 1977. Seed production of F1 hybrid Brussels sprouts. In Symposium on Seed 257 Problems in Horticulture 83: 37-42.

258 Free JB, Williams IH. 1976. Insect pollination of Anacardioum occidentale L., Mangifera indica 259 L. Blighia sapida Koening and Persea americana Mill. Tropical Agriculture 53: 125-139.

260 Gallai N, Salles JM, Settele J, Vaissiere BE. 2009. Economic valuation of the vulnerability of 261 world agriculture confronted with pollinator decline. Ecological Economics 68: 810-821.

262 Garibaldi LA, Steffan-Dewenter I, Winfree R, Aizen MA, Bommarco R, Cunningham SA, Klein 263 264 265 AM. 2013. Wild pollinators enhance fruit set of crops regardless of honey bee abundance. Science 339: 1608-1611.

Garibaldi LA, Steffan-Dewenter I, Kremen C, Morales JM, Bommarco R, Cunningham SA, Carvalheiro LG, Chacoff NP, Dudenhöffer JH, Greenleaf SS, Holzschuh A, Isaacs R, Krewenka K, Mandelik Y, Mayfield MM, Morandin LA, Potts SG, Ricketts TH, Szentgyörgyi H, Viana B, Westphal C, Winfree R, Klein AM. 2011. Stability of pollination services decreases with isolation from natural areas despite honey bee visits. Ecology Letters 14: 1062-1072.

Greenrerc G. 1973. Flies and Disease 2: Princeton University Press.

272 Heard TA. 1999. The role of stingless bees in crop pollination. Annual Review of 273 Entomology 44: 183-206.

274

275

276

277

278

279

280

281

282

Heath 2015. Beneficial aspects of blow flies (Diptera: Calliphoridae). New Zealand Entomologist, 7:3, 343-348, DOI:10.1080/00779962.1982.9722422.

Hopwood J, Black, SH, Lee-Mäder E, Charlap A, Preston R, Mozumder K, Fleury, S. 2015. Literature review: pollinator habitat enhancement and best management practices in highway rights-of-way.

Jarlan A, de Oliveira D, Gingras J. 1997. Pollination by Eristalis tenax (Diptera: Syrphidae) and seed set of greenhouse sweet pepper. Journal of Economic Entomology 90:1646-1649.

Jokes HA, Emsiveller SL. 1934. The use of flies as onion pollinators. Proceedings American Society for Horticultural Science 31:160-164. 
283 Kastinger C, Weber A. 2001. Bee-flies (Bombylius spp., Bombyliidae, Diptera) and the

284

285

286

287

288

289

290

291

292

293

294

295

296

297

298

299

300

301

302

303

304

305

306

307

308

309

310

311 pollination of flowers. Flora 196:3-25.

Kleijn D, Baquero RA, Clough Y, Díaz M, De Esteban J, Fernández F, Gabriel D, Herzog F, Holzschuh A, Jöhl R, Knop E, Kruess A, Marshall EJP, Steffan-Dewenter I, Tscharntke T, Verhulst J, West TM, Yela JL. 2006. Mixed biodiversity benefits of agri-environment schemes in five European countries. Ecology Letters 9: 243-254.

Klein AM, Vaissiere BE, Cane JH, Steffan-Dewenter I, Cunningham SA, et al. 2007. Importance of pollinators in changing landscapes for world crops. Proceedings of the Royal Society of London B 274: 303-313.

Klein AM, Vaissiere BE, Cane JH, Steffan-Dewenter I, Cunningham SA, Kremen C, Tscharntke T. 2007. Importance of pollinators in changing landscapes for world crops. Proceedings of the Royal Society B 274:303-313.

Klein MA, Vaissière BE, James HCI, Cunningham SA, Kremen C, Tscharntke T. 2007. Importance of pollinators in changing landscapes for world crops. Proceeding biological sciences 274: 303-313.

Kugler H. 1950. Der Blütenbesuch der Schlammfliege (Eristalomyia tenax). Zeitschrift für Vergleichende Physiologie 32:328-347.

Kugler H. 1951. Blütenökologische Untersuchungen mit Goldfliegen (Lucilien). Berichte der Deutschen Botanischen Gesellschaft 64:327-341.

Kumari DA, Madhavi J, Bhagwan A, Kumar MR. 2014. Surveillance of pollinators and their behaviour in mango flowers. Plant Archives 14: 727-729.

Larson B, Kevan P, Inouye D. 2001. Flies and flowers: taxonomic diversity of anthophiles and pollinators. Canadian Entomologist 133, 439-465. (doi:10.4039/ent133439-4).

Larson BMH, Kevan PG, Inouye DW. 2001. Flies and flowers: taxonomic diversity of anthophiles and pollinators. Canadian Entomologist 133:439-465.

Losey JE, Vaughan M. 2006. The economic value of ecological services provided by insects. BioScience 56:311-323.

Manning R. 1995. Honeybee pollination technical data. Western Australia Department of Agriculture, Bulletin No. 4298. 
312 Mingjian W, Zi WDY, Jianguo D. 2003. The Investigation of the Varieties of Mango Insect

313 Pollinator in Guangxi and the Preliminary Observation on the Habits and Characteristics of 314 the Activities of Such Insects. Journal of Guangxi Agriculture, S1.

315 Munawar MS, Raja S, Niaz S, Sarwar G. 2011. Comparative performance of honeybees (Apis 316 mellifera L.) and blow flies (Phormia terronovae) in onion (Allium cepa L.) seed setting. 317 Journal of Agricultural Research 49: 49-56.

318 Natural Research Council 2006. Status of Pollinators in North America, National Academic 319 Press

320 Potts S, Petanidou T, Roberts S, Otoole C, Hulbert A, Willmer P. 2006. Plant-pollinator 321 biodiversity and pollination services in a complex Mediterranean landscape. Biological Conservation 129: 519-529. (doi:10.1016/j.biocon.2005.11.019).

Potts S, Woodcock B, Roberts S, Tscheulin T, Pilgrim E, Brown V, Tallowin J. 2009. Enhancing 324 pollinator biodiversity in intensive grasslands. Journal of Applied Ecology 46, 369-379. (doi:10.1111/j.1365-2664.2009.01609.x).

Potts SG, Biesmeijer JC, Kremen C, Neumann P, Schweiger O, Kunin WE. 2010. Global 327 pollinator declines: trends, impacts and drivers. Trends Ecology Evolution 25: 345-353.

Richards AJ. 2001. Does low biodiversity resulting from modern agricultural practice affect crop pollination and yield? Annals of Botany 88: 165-172.

Rotheray GE, Gilbert F. 2011. The Natural History of Hoverflies. Forest Text, Ceredigion, UK.

SAS Institute 2002. The SAS System for Windows, Release 9.0, SAS Institute, Cary, N.C.

Shewell GE, 1987. Calliphoridae, p. 1113-1145. In: McAlpine, J.F., B.V. Peterson, G.E. Shewell HJ, Teskey, JR, Vockeroth DM, Wood (Eds.). Manual of Neartic Diptera. Vol. 2. Ottawa, Monograph/Agriculture Canada, 657.

Singh G. 1988. Insect pollinators of mango and their role in fruit setting. Acta Horticulturae 231: 629- 632.

Singh G. 1997. Pollination, pollinators and fruit setting in mango. Acta Horticulturae 455: 116123.

Skevington JH, Dang PT. 2002. Exploring the diversity of flies (Diptera). Biodiversity 3: 3-27.

Ssymank A, Kearns CA, Pape T, Thompson FC. 2008. Pollinating flies (Diptera): A major contribution to plant diversity and agricultural production. Biodiversity 9:86-89. 
342 Stephen E, Irshad M, Sarwar G. 2016. Pollination Deficit in Mango Orchards at Multan, 343 Pakistan. Pakistan Journal of Zoology 48:35-38.

344 Tjiptono P, Lam PF, Kosiyachinda S, Mendoza DB, Leong PC. 1984. Status of the mango 345 industry in ASEAN. In Mendoza, DB, Jr. Wills RBH, (eds.). Mango: Fruit development, 346 postharvest physiology and marketing in ASEAN, 1-11.

347 Vanbergen AJ, Woodcock BA, Gray A, Grant F, Telford A, Lambdon P, Cavers S. 2014. 348 Grazing alters insect visitation networks and plant mating systems. Funct. Ecology 28: 178349 189. (doi:10.1111/1365-2435. 12191)

350 Vargas J, Wood DM. 2010. Calliphoridae, p. 1297-1304. In: Brown BV, Borkent A, Cumming 351 JM, Wood DM, Woodley NE, Zumbado MA, (Eds.). Manual of Central American Diptera:

352 2. Canada, Ontario, NCR Research Press, 728.

353 Verghese A. 1999. Recent studies on the management of mango stone weevil Sternochetus 354 mangiferae Fab. (Coleoptera: Curculionidae) in South India. In VI International Symposium 355 on Mango 509: 819-822.

356 Zumpt F. 1965: . Mytasts in Man and Animals in the Old World. Butterworths, London. 357

358

359

360

361

362

363

364

365

366

367

368

369

370

371

372 


\begin{tabular}{|c|c|c|c|c|c|}
\hline \multirow[t]{2}{*}{ Treatments } & \multirow[t]{2}{*}{ Trees } & \multicolumn{4}{|c|}{ Number and types of mango inflorescence } \\
\hline & & Conical & Pyramid & Irregular & Total \\
\hline \multirow[t]{3}{*}{ Closed } & Tree 1 & 13.00 & 18.00 & 22.00 & 53.00 \\
\hline & Tree 2 & 15.00 & 34.00 & 20.00 & 69.00 \\
\hline & Tree 3 & 34.00 & 19.00 & 33.00 & 86.00 \\
\hline \multirow[t]{3}{*}{ Blow flies } & Tree 1 & 19.00 & 21.00 & 21.00 & 61.00 \\
\hline & Tree 2 & 11.00 & 13.00 & 12.00 & 36.00 \\
\hline & Tree 3 & 20.00 & 34.00 & 20.00 & 74.00 \\
\hline \multirow[t]{3}{*}{ Open } & Tree 1 & 45.00 & 50.00 & 30.00 & 125.00 \\
\hline & Tree 2 & 27.00 & 23.00 & 26.00 & 76.00 \\
\hline & Tree 3 & 23.00 & 43.00 & 20.00 & 86.00 \\
\hline
\end{tabular}




\section{Figure Legends}

377 1. Mango tree was covered with muslin cloth

378 2. Effect of different pollination methods on the different types of mango flowers

3793 . Effect of different pollination methods on the bud formation/inflorescence after 15 days of 380 treatment

381 4. Effect of different pollination methods on the bud formation/inflorescence after 10 days after 382 the treatments

383 5. Effect of different pollination methods on the number of fruits at marble stage

6. Effect of different pollination methods on the fruit size and weight at marble stage

7. Correlation between mango fruit size and weight at marble stage

386

387

388

389

390

391

392

393

394

395

396

397 
400

401

402

403

404

405

406

407

408

409

410

411 


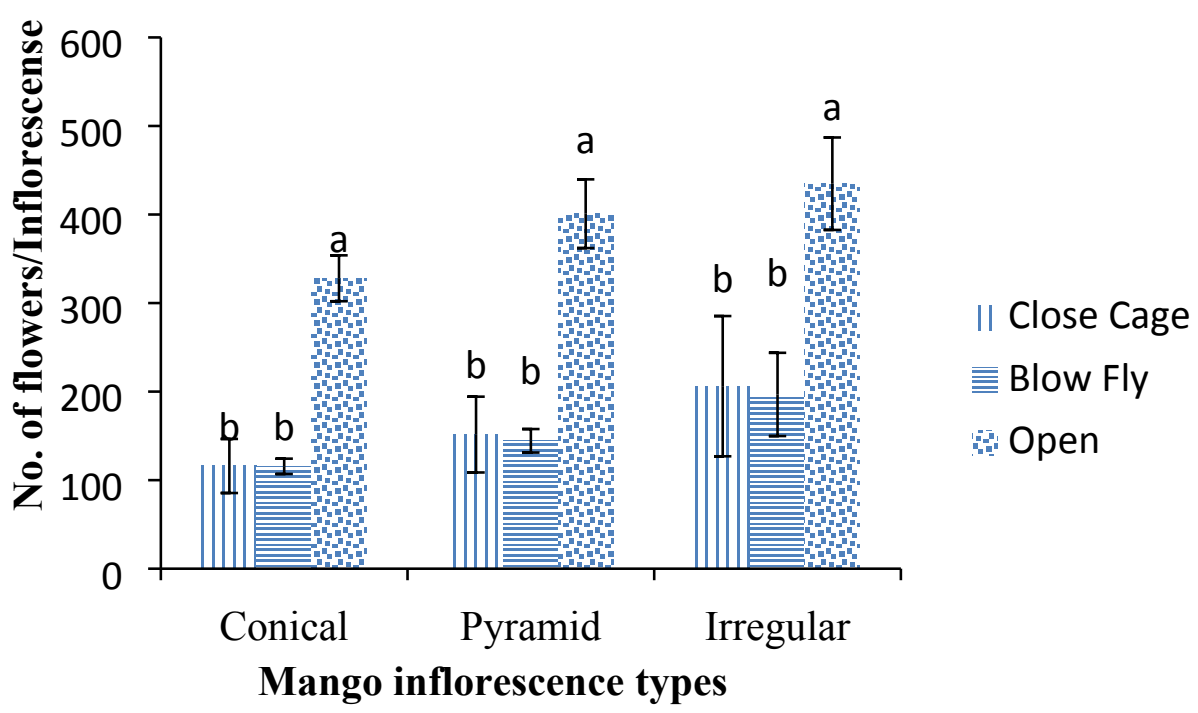

412

413

414

415

416

417

418

419

420

421
Fig 2. Effect of different pollination methods on the different types of mango flowers Mean values sharing similar letters did not differ significantly with in the treatments $(\mathrm{P} \leq 0.001)$. Bars indicate the standard deviation (SD) of the observation 


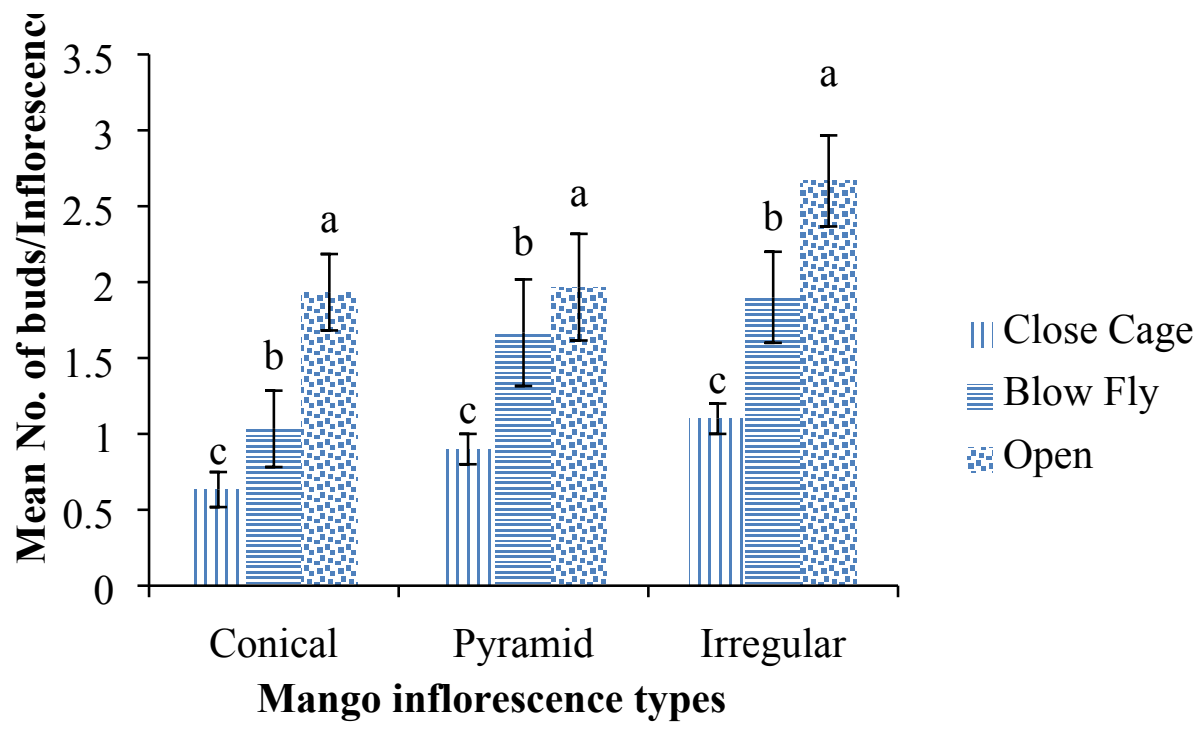

422

423 Fig 3. Effect of different pollination methods on the bud formation/inflorescence after 15 days of 424 treatment

425 Mean values sharing similar letters did not differ significantly with in the treatments $(\mathrm{P} \leq 0.001)$.

426 Bars indicate the standard deviation (SD) of the observation

427

428

429

430

431

432

433

434

435

436

437

438

439

440 


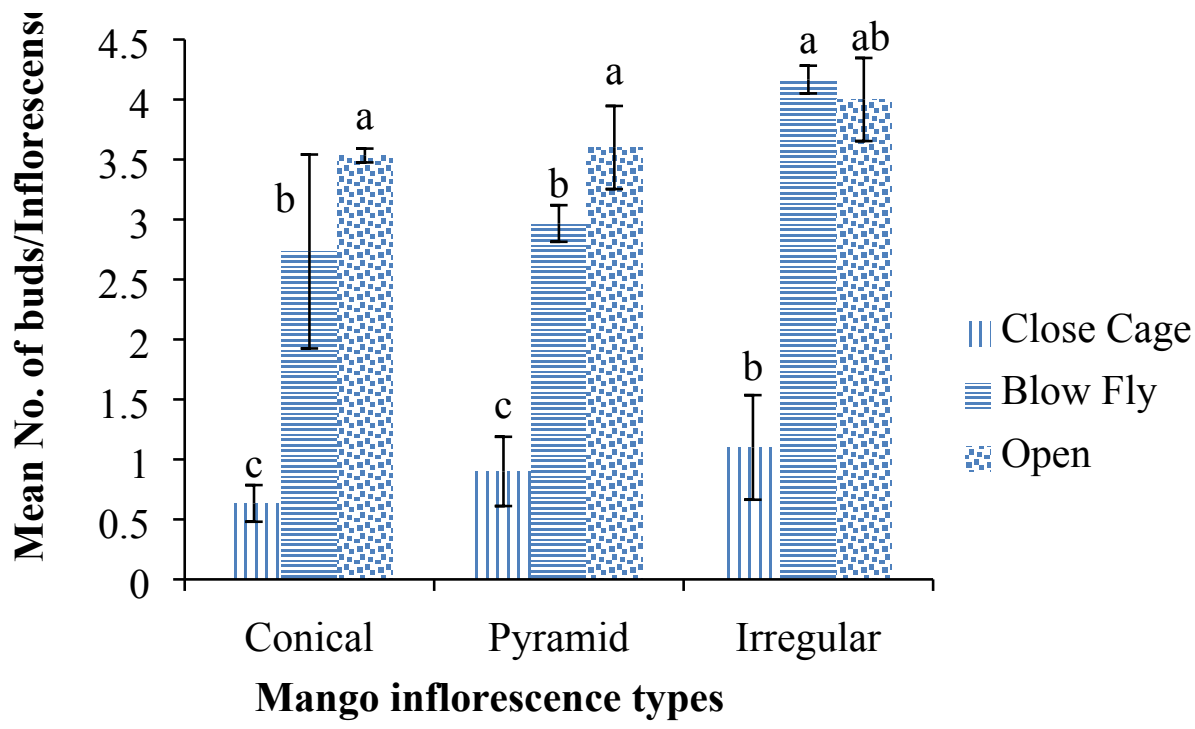

441

442 Fig 4. Effect of different pollination methods on the bud formation/inflorescence after 10 days 443 after the treatments

444 Mean values sharing similar letters did not differ significantly with in the treatments $(\mathrm{P} \leq 0.001)$.

445 Bars indicate the standard deviation (SD) of the observation

446 


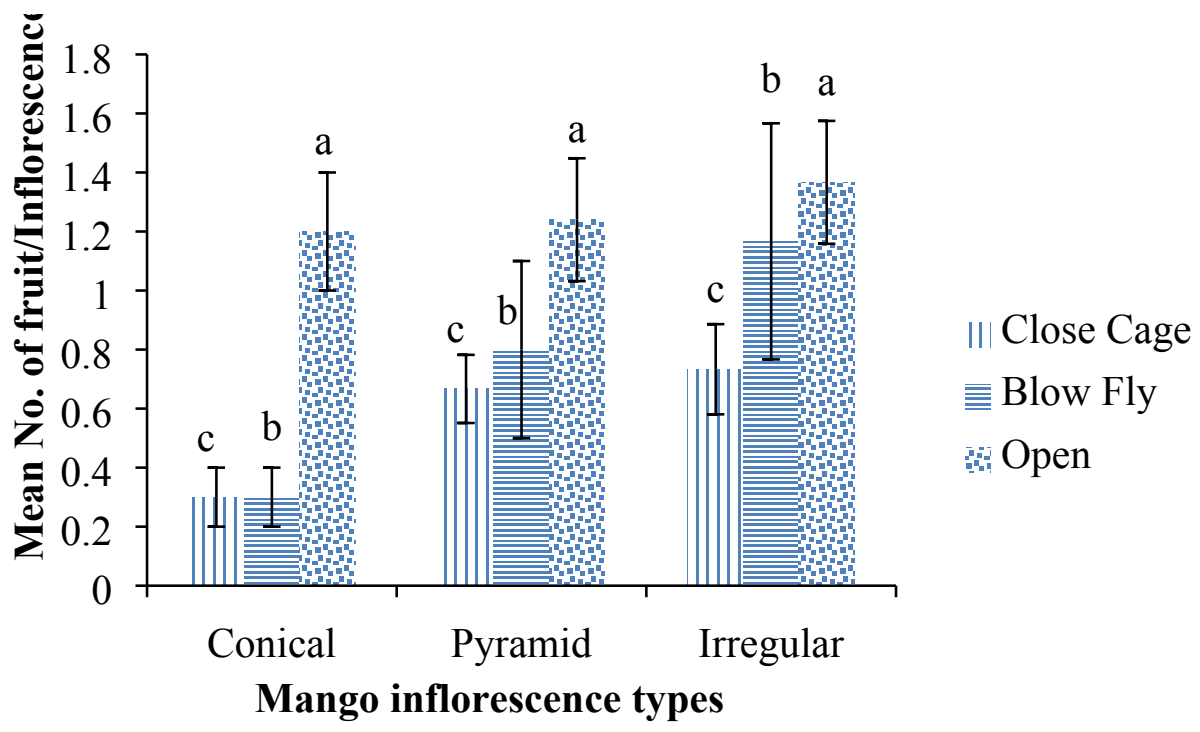

447

448 Fig 5. Effect of different pollination methods on the number of fruits at marble stage 449 Mean values sharing similar letters did not differ significantly with in the treatments $450 \quad(\mathrm{P} \leq 0.001)$. Bars indicate the standard deviation $(\mathrm{SD})$ of the observation

451

452

453

454

455

456

457

458

459

460

461 


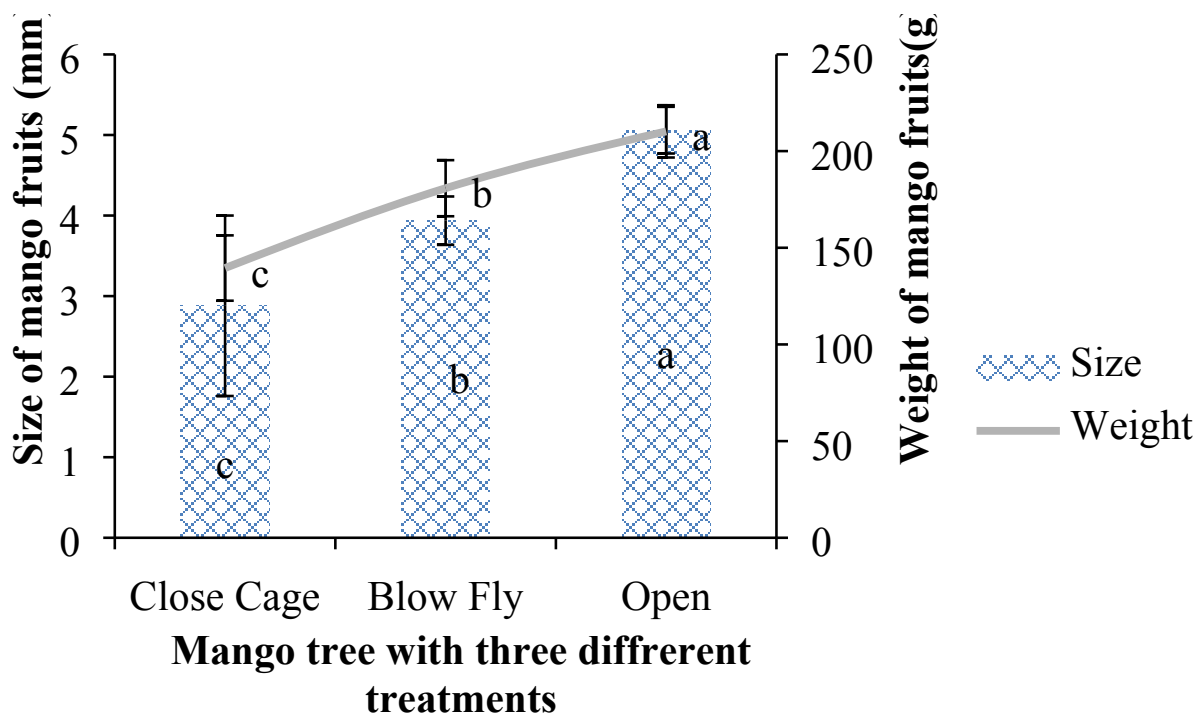

462

463 Fig 6. Effect of different pollination methods on the fruit size and weight at marble stage

464 Mean values sharing similar letters did not differ significantly with in the treatments

$465(\mathrm{P} \leq 0.001)$. Bars indicate the standard deviation $(\mathrm{SD})$ of the observation

466

467

468

469

470

471

472

473 


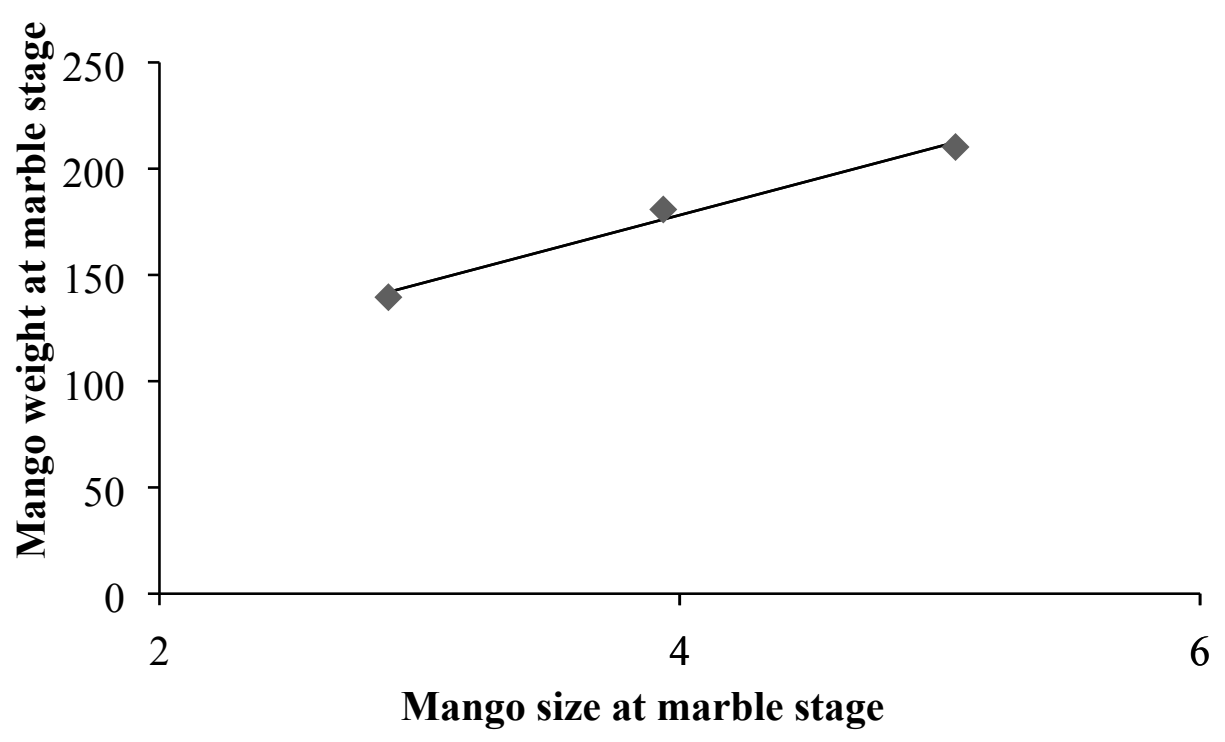

474

475

476

477

478

479

480 